\title{
Effects of metoclopramide on the expression of metalloproteinases and interleukins in left colonic anastomoses. An experimental study ${ }^{1}$
}

\author{
Silvana Marques e Silva ${ }^{\mathrm{I}}$, Márcio Sousa Jerônimo ${ }^{\mathrm{II}}$, Ildinete da Silva-Pereira ${ }^{\mathrm{III}}$, Aldo Henrique Tavares ${ }^{\mathrm{IV}}$, Anamélia Lorenzetti \\ Bocca $^{\mathrm{V}}$, João Batista de Sousa ${ }^{\mathrm{VI}}$
}

DOI: http://dx.doi.org/10.1590/S0102-865020150110000007

${ }^{\mathrm{I}} \mathrm{PhD}$, Clinical Surgery, School of Medicine, Universidade de Brasilia (UnB), Brazil. Design of the study, technical procedures, statistical analysis, analysis of data, manuscript writing.

IIFellow PhD degree, Postgraduate Program in Molecular Pathology, School of Medicine, UnB, Brasilia-DF, Brazil. Design of the study, analysis of data.

IIIPhD, Associate Professor, CNPQ 1D, Cell Biology, Biology Institute, UnB, Brasilia-DF, Brazil. Design of the study, analysis of data, critical revision. ${ }^{\text {IV }} \mathrm{PhD}$, Associate Professor, Cell Biology, Biology Institute, UnB, Brasilia-DF, Brazil. Design of the study, analysis of data, critical revision.

${ }^{\mathrm{V}} \mathrm{PhD}$, Associate Professor, CNPQ 2, Cell Biology, Biology Institute, UnB, Brasilia-DF, Brazil. Design of the study, analysis of data, critical revision. ${ }^{v 1 P h D}$, Associate Professor, Surgical Clinics, Faculty of Medicine, UnB, Brasilia-DF, Brazil. Design of the study, technical procedures, statistical analysis, critical revision.

\section{ABSTRACT}

PURPOSE: To evaluate the effects of metoclopramide on metalloproteinases (MMP) and interleukins (IL) gene expression in colonic anastomoses in rats.

METHODS: Eighty rats were divided into two groups for euthanasia on the 3rd or 7th postoperative day (POD), then into two subgroups for sepsis induction or not, and then into subgroups to receive either metoclopramide or saline solution. Left colonic anastomosis were performed and then analyzed.

RESULTS: On the 3rd POD, metoclopramide was associated with increased expression of MMP-1a, MMP-13, and TNF- $\alpha$. On the 7th POD, the transcripts of all MMPs, TNF- $\alpha$, IL-1 $\beta$, IFN- $\gamma$, and IL-10 of the treated animals became negatively modulated. In the presence of sepsis, metoclopramide did not change MMPs and decreased IL-6, IL-1 $\beta$, IFN- $\gamma$ and IL-10 gene expression on the 3rd POD. On the 7th POD, increased expression of all MMPs, IFN- $\gamma$ and IL-10 and negative modulated TNF- $\alpha$ and IL- 6 gene expression.

CONCLUSION: Administration of metoclopramide increased metalloproteinases and interleukins gene expression on the 3rd postoperative day and negatively modulated them on the 7th POD. In the presence of abdominal sepsis, metoclopramide did not change MMPs and decreased ILs gene expression on the 3rd POD. On the 7th POD, the drug increased expression of all MMPs.

Key words: Interleukins. Matrix Metalloproteinases. Metoclopramide. Anastomosis, Surgical. Rats. 


\section{Introduction}

Anastomotic dehiscence is the most severe complication of colorectal surgery, occurring in 2.4 to $3.8 \%$ of the cases ${ }^{1}$.

Different parameters can be used to analyze the healing process of anastomosis. Matrix metalloproteinases (MMPs) are a family of at least 20 zinc-dependent endopeptidases involved in the degradation of extracellular matrix components. MMP-1, MMP-8 and MMP-13 are collagenases and cleave types I and III collagen fibrils ${ }^{2}$. An increased presence of active forms of MMPs may lead to localized matrix degradation and a transient loss of strength in the anastomosed segment, thus leading to anastomotic dehiscence ${ }^{3}$.

Another important healing parameter is cytokine expression in the anastomotic area. Several authors have assessed cytokine levels in the postoperative period and their relationship to anastomotic complications ${ }^{4-7}$. During the healing process, cytokines and chemokines interact to determine the strength of the inflammatory response and the extent of subsequent adhesion formation ${ }^{8}$. These interactions are complex and produce both proand anti-inflammatory cytokines. Pro-inflammatory cytokines include tumor necrosis factor- $\alpha$ (TNF- $\alpha$ ), interleukin (IL)-1 $\beta$, IL-6 and IL-8, while anti-inflammatory molecules include IL-4 and IL10.

Many experimental studies have been carried out to assess colonic anastomotic healing and factors contributing to anastomotic failure, such as fecal contamination and drug administration $^{8}$. Metoclopramide (methoxy-2-chloro-5procainamide) is an antiemetic prokinetic agent that stimulates gastrointestinal motility and has been used to treat paralytic ileus and to control postoperative vomiting.

The aim of this study was to evaluate the effects of metoclopramide on MMP and IL gene expression in left colonic anastomoses in rats with or without induced abdominal sepsis.

\section{Methods}

The study was approved by the Animal Ethics Committee (AEC) of the Institute of Biological Sciences of Universidade de Brasília (UnB), protocol no. 67336/2009, Brazil. All procedures were carried out in accordance with the Brazilian guidelines for use of animals in research.

Eighty healthy male Wistar rats (Rattus norvergicus) aged 90 to 120 days were used in the study. Throughout the 2-week preoperative period, the animals were housed in cages with five animals each and kept under a standard 12:12-hour artificial light/ dark cycle. Animals were fed standard chow and water ad libitum. There was no preoperative fasting period.

\section{Experimental protocol}

The rats were randomly divided into two groups of 40 animals each for euthanasia on the $3 \mathrm{rd}$ or 7 th postoperative day (POD). Further randomization was performed, and the animals were divided into subgroups of 20 rats each for sepsis induction or not (sepsis/no sepsis), and then into subgroups of 10 rats each to receive either metoclopramide or saline solution (Figure 1).

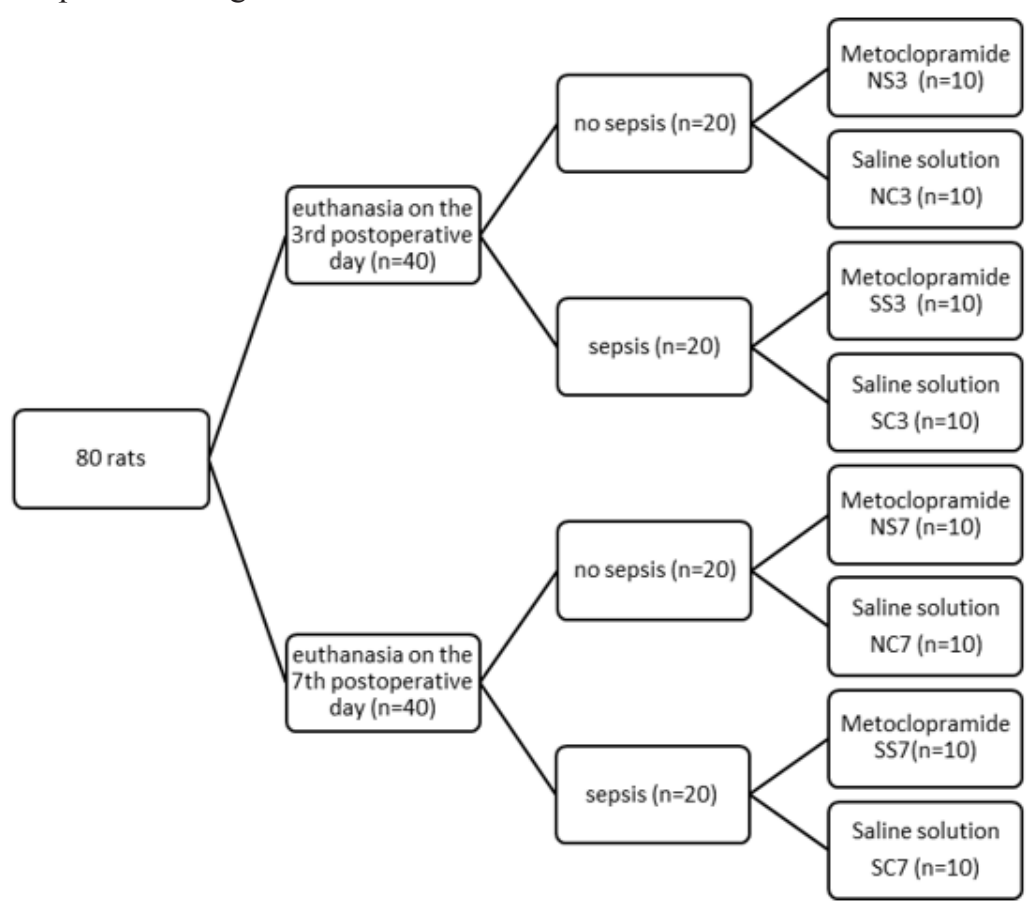

FIGURE 1 - Allocation of animals to groups and subgroups. 
General anesthesia was performed with xylazine hydrochloride $(10 \mathrm{mg} / \mathrm{kg})$ and ketamine hydrochloride $(75 \mathrm{mg}$ / $\mathrm{kg}$ ) administered intramuscularly. All surgical procedures were performed by the same surgeon.

The surgical site was shaved and disinfected with povidone-iodine. Clean, non-sterile surgical instruments were used. A 4.0-cm midline laparotomy incision was made, starting $1.0 \mathrm{~cm}$ above the external genitalia. The distal colon was exposed, and a $0.5-\mathrm{cm}$ segment of the left colon $(2.5$ to $3.0 \mathrm{~cm}$ above the peritoneal reflection) was resected, followed by end-to-end anastomosis of the resulting segment, in a single transmural plane, using continuous 6-0 polypropylene suture and a cylindrical needle.

After anastomosis, in the animals in the sepsis group, abdominal sepsis was experimentally induced using the cecal ligation and puncture (CLP) method, as described by Rittirsch et $a l .{ }^{9}$ - one half of the cecum was ligated using 3-0 silk thread $\left(\right.$ Shalon $\left.^{\circledR}\right)$. The end of the cecum, located distal to the ligation, was punctured at 10 random sites using an 18Gx1 1/2" (40x12mm) venipuncture needle, and some fecal content was extruded. The abdominal wall was closed in two planes with a simple running suture (3-0 silk thread).

Animals that died within the first 24 postoperative hours were excluded from the study. Metamizole sodium monohydrate $(20 \mathrm{mg} / \mathrm{kg}$ ) was added to the animals' water for analgesia until the day of euthanasia. No antibiotics were used.

After the operations, metoclopramide was administered to animals in the experimental subgroups at a dose of $1 \mathrm{mg} / 100$ g, subcutaneously, every 12 hours until the animal was killed. Control animals received identical amounts of saline solution, subcutaneously, every 12 hours.

Reoperation was performed on the scheduled day for each subgroup. After exposure, the abdominal cavity was assessed for anastomotic dehiscence. A 4.0-cm colonic segment, with the anastomosis at the center, was removed en bloc together with any adherent structures.

Animals were killed with an overdose of sodium thiopental $(150 \mathrm{mg} / \mathrm{kg})$ administered directly into the inferior vena cava.

\section{Specimen preparation}

After resection of the adherent structures, specimens were opened at the antimesenteric border and divided into longitudinal sections for later analysis of the gene expression of MMP-1a, MMP-8, MMP-13, IL-1 $\beta$, IL-6, IL-10, TNF- $\alpha$, and interferon- $\gamma$ (IFN- $\gamma$ ).

The anastomotic segment was macerated in TRI Reagent ${ }^{\mathbb{B}}$ solution (Applied Biosystems, Foster City, CA, USA). RNA was isolated by a single extraction with a phenol-chloroform mixture and treated with Promega ${ }^{\circledR}$ DNAse in the presence of an RNAse inhibitor (Promega, cat\#M6101; Lot\# 262753) in order to remove all traces of residual genomic DNA contamination, according to the protocol. Equal amounts of RNA $(0.4 \mu \mathrm{g})$ were subjected to reverse transcription with High Capacity cDNA Reverse Transcription Kits (Applied Biosystems).

Real-time quantitative reverse transcription polymerase chain reaction (qRT-PCR) was performed using a 7500 Fast RealTime PCR System (Applied Biosystems). Amplification of cDNA sequences was performed using the PCR Master Mix kit (Applied Biosystems) containing the $\mathrm{SYBR}^{\circledR}$ Green intercalating agent, a fluorescent molecule that intercalates into double-stranded DNA after initial denaturation at $95^{\circ} \mathrm{C}$ for 15 seconds, followed by $60^{\circ} \mathrm{C}$ for 1 minute.

To confirm amplification specificity, PCR products were analyzed by denaturation curves or melting curves. Comparisons were made using the threshold cycle $(\mathrm{Ct})$ or crossing point $(\mathrm{Cp})^{10}$ method with cyclophilin to normalize values in order to assess the variation in fold-change expression of each gene. The foldchange expression represents the ratio of the measured value for the treated animals to the value for the non-treated cohorts. Values greater than 2.0 were considered positively modulated, whereas values less than 0.5 were negatively modulated. We considered that there was no change in gene expression in the range between these values. Reactions were performed in triplicate for all genes analyzed. All oligonucleotide pairs were designed using the Primer Express ${ }^{\circledR}$ software (Applied Biosystems), and they are listed in Table 1. 
TABLE 1 - Genes and oligonucleotides used in real-time quantitative reverse transcription polymerase chain reaction (qRTPCR).

\begin{tabular}{|c|c|}
\hline Genes & Oligos \\
\hline Cyclophilin & $\begin{array}{c}\text { 5' - TAT CTG CAC TGC CAA GAC TGA GTG - 3' F } \\
\text { 5' - CTT CTT GCT GGT CTT GCC ATT CC - 3' R }\end{array}$ \\
\hline TNF- $\alpha$ & $\begin{array}{l}\text { 5' - AAA TGG GCT CCC TCT CAT CAG TCC - 3’ F } \\
\text { 5' - TCT GCT TGG TGG TTT GCT ACG AC - 3’ R }\end{array}$ \\
\hline IL-6 & $\begin{array}{l}\text { 5'- TCC TAC CCC AAC TCC CAA TGC TC - 3' F } \\
\text { 5'- TTG GAT GGT CTT GGT CCY YAG CC - 3' R }\end{array}$ \\
\hline IL-1及 & $\begin{array}{l}\text { 5'- CAC CTC TCA AGC AGA GCA CAG - 3' F } \\
\text { 5'- GGG TTG CAT GGT GAA GTC AAC - 3’ R }\end{array}$ \\
\hline IL-10 & $\begin{array}{l}\text { 5' - CAG ACC CAC ATG CTC CGA GA - 3’ F } \\
\text { 5' - CAA GGC TTG GCA ACC CAA GTA - 3’ R }\end{array}$ \\
\hline IFN- $\gamma$ & $\begin{array}{l}\text { 5' - GAT CCA GCA CAA AGC TGT CA - 3' F } \\
\text { 5'- GAC TCC TTT TCC GCT TCC TT- 3' R }\end{array}$ \\
\hline MMP-1a & $\begin{array}{l}\text { 5'- AGG AGC ACT AAT GTT CCC CAG CT - 3’ F } \\
\text { 5'- TGG GAT TTG GGG AAG GCC CAT A - 3' R }\end{array}$ \\
\hline МMP-8 & $\begin{array}{l}\text { 5'- GGA GTG TGC CAT CAA CCC TGA CC - 3' F } \\
\text { 5'- TGT CAC CAT GGT CTC TTG AGA CGA - 3' R }\end{array}$ \\
\hline ММР-13 & $\begin{array}{l}\text { 5'- ACC CAG CCC TAT CCC TTG ATG CC - 3’ F } \\
\text { 5’- GGT GCA GAC GCC AGA AGA ATC TGT - 3’ R }\end{array}$ \\
\hline
\end{tabular}

$\mathrm{IFN}=$ interferon; $\mathrm{IL}=$ interleukin; $\mathrm{MMP}=$ matrix metalloproteinase $; \mathrm{TNF}=$ tumor necrosis factor.

\section{Results}

Effects of metoclopramide on non-septic rats

There were no deaths in either group on the $3 \mathrm{rd}$ or 7 th POD. There was no anastomotic dehiscence on the 3rd POD.
On the 7th POD, one animal in the treated subgroup (NS7) had anastomotic dehiscence blocked by adjacent organs, which was noticed only after opening the surgical specimen.

Administration of metoclopramide was associated with increased MMP-1a and MMP-13 expression on the 3rd POD. On the 7th POD, the transcripts of all MMPs of all treated animals became negatively modulated (Table 2).

TABLE 2 - Fold-change expression assessed on the 3rd and 7th postoperative days (metalloproteinases) in non-septic rats: treated animals vs. non-treated cohorts.

\begin{tabular}{cccc}
\hline Subgroup & MMP-1a & Gene & MMP-8 \\
\hline NS3 & $39.96720( \pm 10.32386)$ & $0.44079( \pm 0.08206)$ & $5.12306( \pm 2.61933)$ \\
NS7 & $0.00135( \pm 0.00096)$ & $0.00015( \pm 0.00004)$ & $0.02294( \pm 0.02283)$ \\
\hline
\end{tabular}

$\mathrm{MMP}=$ matrix metalloproteinase; NS3 = non-septic rats receiving metoclopramide euthanized on the 3rd postoperative day; NS7 = non-septic rats receiving metoclopramide euthanized on the 7 th postoperative day.

On the 3rd POD, administration of metoclopramide positively modulated TNF- $\alpha$ gene expression and negatively modulated IL-6, IL-1 $\beta$, and IL-10. On the 7th POD, negative modulation of TNF- $\alpha$, IL-1 $\beta$, IFN- $\gamma$ and IL-10 was observed in all treated animals (Table 3 ). 
TABLE 3 - Fold-change expression assessed on the 3rd and 7th postoperative days (interleukins) in non-septic rats: treated animals vs. non-treated cohorts.

\begin{tabular}{cccccc}
\hline Subgroup & TNF- $\alpha$ & IL-6 & Gene \\
IL-1 & IFN- $\boldsymbol{\gamma}$ & IL-10 \\
\hline NS3 & $39.61586( \pm 11.90558)$ & $0.13742( \pm 0.08054)$ & $0.02908( \pm 0.01590)$ & $1.12636( \pm 0.57227)$ & $0.02161( \pm 0.00937)$ \\
NS7 & $0.41796( \pm 0.18294)$ & $0.55071( \pm 0.75599)$ & $0.00272( \pm 0.00219)$ & $0.38569( \pm 0.32737)$ & $0.00826( \pm 0.00817)$ \\
\hline
\end{tabular}

IFN = interferon; IL = interleukin; TNF = tumor necrosis factor; NS3 = non-septic rats receiving metoclopramide euthanized on the 3rd postoperative day; NS7 = nonseptic rats receiving metoclopramide euthanized on the 7 th postoperative day.

\section{Effects of metoclopramide on septic rats}

There were no deaths in the group killed on the 3rd POD. There was one death in each subgroup of septic animals scheduled to be killed on the 7th POD. None of the deaths was related to anastomotic dehiscence.

On the 3rd POD, one animal in the non-treated subgroup
(SC3) had free anastomotic dehiscence. On the 7th POD, one animal in each subgroup (SC7 e SS7) had anastomotic dehiscence blocked by adjacent organs, which was noticed only after opening the surgical specimen.

On the 3rd POD, administration of metoclopramide did not change MMP gene expression; however, increased expression of all MMPs was observed on the 7th POD (Table 4).

TABLE 4 - Fold-change expression assessed on the 3rd and 7th postoperative days (metalloproteinases) in septic rats: treated animals vs. non-treated cohorts .

\begin{tabular}{cccc}
\hline Subgroup & Mmp1a & Gene & \\
\hline SS3 & $1.92786( \pm 1.13530)$ & Mmp 8 & Mmp13 \\
SS7 & $3.39068( \pm 0.37667)$ & $1.99820( \pm 0.20220)$ & $1.87653( \pm 0.32977)$ \\
\hline
\end{tabular}

$\mathrm{MMP}=$ matrix metalloproteinase; SS3 = septic rats receiving metoclopramide euthanized on the 3rd postoperative day; SS7 = septic rats receiving metoclopramide euthanized on the 7th postoperative day.

On the 3rd POD, administration of metoclopramide was associated with increased expression of TNF- $\alpha$. In the same period, IL-6, IL-1 $\beta$, IFN- $\gamma$ and IL-10 gene expression were negatively modulated. On the 7th POD, treated animals had increased IFN- $\gamma$ and IL-10 gene expression. TNF- $\alpha$ and IL-6 gene expression were negatively modulated (Table 5).

TABLE 5 - Fold-change expression assessed on the 3rd and 7th postoperative days (interleukins) in septic rats: treated animals vs. non-treated cohorts.

\begin{tabular}{|c|c|c|c|c|c|}
\hline \multirow[b]{2}{*}{ Subgroup } & \multicolumn{5}{|c|}{ Gene } \\
\hline & TNF- $\alpha$ & IL-6 & IL-1及 & IFN- $\gamma$ & IL-10 \\
\hline SS3 & $\begin{array}{c}911.6366 \\
( \pm 461.2386)\end{array}$ & $\begin{array}{c}0.1381 \\
( \pm 0.0377)\end{array}$ & $\begin{array}{c}0.4270 \\
( \pm 0.0553)\end{array}$ & $\begin{array}{c}0.3615 \\
( \pm 0.2322)\end{array}$ & $\begin{array}{c}0.0033 \\
( \pm 0.0025)\end{array}$ \\
\hline SS7 & $\begin{array}{c}0.4402 \\
( \pm 0.1878)\end{array}$ & $\begin{array}{c}0.0219 \\
( \pm 0.0020)\end{array}$ & $\begin{array}{c}0.8384 \\
( \pm 0.0806)\end{array}$ & $\begin{array}{c}27.0711 \\
( \pm 3.2213)\end{array}$ & $\begin{array}{c}107.3627 \\
( \pm 42.6794)\end{array}$ \\
\hline
\end{tabular}

IFN = interferon; IL = interleukin; TNF = tumor necrosis factor; SS3 = septic rats receiving metoclopramide euthanized on the 3rd postoperative day; SS7 = septic rats receiving metoclopramide euthanized on the 7 th postoperative day.

\section{Discussion}

The colon is the site of the gastrointestinal tract most vulnerable to anastomotic leakage. High mortality and severe morbidity associated with dehiscence support the need for further research into the evaluation of the deleterious effects of drugs and infection on wound healing.

Metoclopramide is a prokinetic agent often used in the postoperative period after colorectal surgery, and the CLP method is one of the most commonly used models to study 
the pathophysiology of abdominal sepsis and its systemic consequences $^{11}$.

The expression of most MMPs is transcriptionally regulated by growth factors, hormones, cytokines, and cell transformation. MMPs are secreted into the extracellular environment as zymogens or pro-MMPs on demand, except in the case of neutrophils, macrophages, and Paneth's cells, in which MMPs are stored in granules ${ }^{12}$. They are involved in many different and fundamental biological processes, such as coagulation, immunity, inflammation, angiogenesis, tissue removal, connective tissue remodeling, and epithelial cell and fibroblast migration ${ }^{12,13}$.

Under normal conditions, the expression of MMPs is restricted to a few tissues which show intense remodeling, such as the endometrium during the menstrual cycle, healing wounds, and tissues undergoing inflammatory reaction ${ }^{13}$. Therefore, MMPs are absent in normal colon but can be seen in the suture line after anastomosis.

Controlling the activity of MMPs is essential to prevent excessive breakdown, which may result in anastomotic dehiscence and its associated increase in morbidity and mortality, or insufficient breakdown, which may result in fibrosis and stricture formation ${ }^{14}$. Patients with increased MMP-1, MMP-2 and MMP-9 in perioperative colonic biopsies have shown increased rates of anastomotic dehiscence ${ }^{15}$. Furthermore, the inhibition of MMP activity has enhanced the healing of colonic anastomoses, with higher burst pressure and increased amount of collagen fibers in the submucosal layer at the anastomotic site ${ }^{16}$.

It has been suggested that matrix degradation may be increased by unspecified mechanisms during bacterial peritonitis ${ }^{17}$. The origin of the increased MMP level in healing anastomoses during peritonitis remains a matter of speculation and may be due to an increased number of inflammatory cells present close to the healing anastomosis during infectious processes, such as polymorphonuclear cells, macrophages, and monocytes ${ }^{17}$.

In previous studies, we found that metoclopramide had no harmful effects on the healing of intestinal anastomoses in rats in the presence ${ }^{18}$ or absence ${ }^{19}$ of abdominal sepsis after tensile strength testing, measurement of hydroxyproline levels, histomorphometric evaluation of collagen, and histopathological analysis. Although the difference was not statistically significant, we noted that, in the absence of peritoneal sepsis, the anastomoses of metoclopramidetreated animals had lower anastomotic breaking strength on the 3rd POD and higher values on the 7th POD, compared to saline solution-treated controls ${ }^{19}$. This might be explained in the present study by the increased expression of MMP-1a and MMP-13 on the 3rd POD and the subsequent negative modulation of all MMPs on the 7th POD in the anastomoses of all metoclopramide-treated animals.

Under septic conditions, our previous study showed no statistical difference across groups in the rates of tensile strength neither on the 3 rd nor on the 7 th POD $^{18}$. In the present study, under septic conditions, on the 3rd POD administration of metoclopramide did not change MMP gene expression, but on the 7th POD we could observe an increased expression of all MMPs. In spite of that, there was no evidence of a greater number of anastomotic leaks in the treated group.

In a previous study, in which we investigated the isolated effect of CLP-induced abdominal sepsis on anastomotic healing, we found that, in the absence of drug administration, infection reduced the breaking strength of left colonic anastomoses on the 3 rd POD, but enhanced values were observed on the 7 th POD $^{20}$. Abdominal sepsis was associated with increased MMP-1a gene expression and reduced MMP-8 gene expression both on the 3rd and 7th POD. There was no change in MMP-13 gene expression ${ }^{21}$.

Nevertheless, it is important to point out that the study of MMP activity by immunohistochemical staining or mRNA analysis does not necessarily mean that matrix degradation will occur, since strict control of MMP activity is preserved when MMPs are released as inactive pro-enzymes or by the presence of inhibitors ${ }^{22}$.

After trauma, cytokines are primarily synthesized and released at the site of injury and subsequently released systemically ${ }^{5}$. IL- $1 \beta$ is the first warning sign of adjacent cells after tissue damage ${ }^{23}$. It induces secretion of IFN- $\gamma$, IL-6, and MMPs ${ }^{24}$. TNF- $\alpha$ is an inflammatory mediator that plays an active role in collagen synthesis and also provides metabolic substrate for wound healing during the inflammatory phase ${ }^{25}$. Increased TNF- $\alpha$ levels after 24 hours are correlated with delayed healing ${ }^{6}$.

IL-6 plays an active role in modulating proliferation, differentiation and maturation of several cell types ${ }^{7}$. Studies have reported increased IL-6 and TNF- $\alpha$ levels in patients with postoperative complications ${ }^{26}$. IFN- $\gamma$ is involved in the inflammatory response that involves immune pathways. IL-10 is one of the most widely known negative markers of inflammation ${ }^{27}$. This cytokine increases 24 hours after surgical procedures, reducing pro-inflammatory cytokines, such as TNF- $\alpha$ and IL- ${ }^{6}$.

Many authors have studied the variation in cytokine levels in the postoperative period and the occurrence of complications ${ }^{5}$. Herwig et al..$^{4}$ showed that a marked increase in IL-6 and TNF- $\alpha$ levels may be considered a precursor event occurring days before the secondary clinical signs of anastomotic leakage and that the increase in IL-1 $\beta$ cytokine levels became statistically significant 
on the 3rd POD in patients who had anastomotic dehiscence. Also, a positive correlation has been described between IL-1 $\beta$, IL-6 and TNF- $\alpha$ levels and prolonged operative time, blood loss and bacterial contamination of peritoneal fluid ${ }^{28}$.

In our previous study ${ }^{21}$, the anastomoses of animals subjected to CLP showed negative modulation of IL-6, IL-1 $\beta$ and IFN- $\gamma$ gene expression both on the 3 rd and 7 th POD. There was an increase in the gene expression of TNF- $\alpha$ only on the 7th POD and of IL-10 on the 3rd POD.

Some authors, investigating the effects of metoclopramide administration on cytokine release in mixed splenocyte cultures in CLP or sham-operated mice, noticed no effects on untreated or sham-operated groups, but sepsis was associated with a significantly decrease in IL-6 and IFN- $\gamma$ release. Administration of metoclopramide in septic mice normalized the release of IL-6 and IFN- $\gamma^{29}$.

In the present study, on the 3rd POD, administration of metoclopramide positively modulated TNF- $\alpha$ and negatively modulated IL-6, IL-1 $\beta$ and IL-10 gene expression both in the presence and absence of abdominal sepsis. On the 7th POD, metoclopramide-treated animals showed negative modulation of TNF- $\alpha$ in both septic and non-septic conditions, but had increased IFN- $\gamma$ and IL-10 gene expression in the presence of abdominal sepsis.

However, it is important to highlight that the detection of cytokine gene expression or even cytokine levels in tissues or secretions does not necessarily correlate with its biological activity. Cytokines may not have been produced, but rather may have been released as inactive pro-enzymes or may have already been degraded ${ }^{30}$.

\section{Conclusions}

Administration of metoclopramide increased MMP and IL gene expression on the 3rd POD and negatively modulated them on the 7th POD. In the presence of abdominal sepsis, metoclopramide did not change MMPs and decreased ILs gene expression on the 3rd POD. On the 7th POD, the drug increased expression of all MMPs and negatively modulated TNF- $\alpha$ and IL-6 gene expression.

\section{References}

1. Buchs NC, Gervaz P, Secic M, Bucher P, Mugnier-Konrad B, Moerl P. Incidence, consequences, and risk factors for anastomotic dehiscence after colorectal surgery: a prospective monocentric study. Int J Colorectal Dis. 2008 Mar;23(3):265-70. PMID: 18034350.
2. Stamenkovic I. Extracellular matrix remodelling: the role of matrix metalloproteinases. J Pathol. 2003;200:448-64. PMID: 12845612.

3. Hingh IH, Siemonsma MA, Man BM, Lomme RM, Hendriks T. The matrix metalloproteinase inhibitor BB-94 improves the strength of intestinal anastomoses in the rat. Int J Colorectal Dis. 2002 Sep;17(5):348-54. PMID: 12172929.

4. Herwig R, Glodny B, Kuhle C, Schluter B, Brinkmann OA, Strasser $\mathrm{H}$, Senninger N, Winde G. Early identification of peritonitis by peritoneal cytokine measurement. Dis Colon Rectum. 2002 Apr;45(4):514-21. PMID: 12006934.

5. Baker EA, El-Gaddal S, Williams L, Leaper DJ. Profiles of inflammatory cytokines following colorectal surgery: relationship with wound healing and outcome. Wound Repair Regen. 2006 SepOct;14(5):566-72. PMID: 17014668.

6. Ishimura K, Moroguchi A, Okano K, Maeba T, Maeta H. Local expression of tumor necrosis factor-alpha and interleukin-10 on wound healing of intestinal anastomosis during endotoxemia in mice. J Surg Res. 2002 Nov;108(1):91-7. PMID: 12443720.

7. Mateo RB, Reichner JS, Albina JE. Interleukin-6 activity in wounds. Am J Physiol. 1994 Jun;266(6 Pt 2):R1840-4. PMID: 8024036.

8. Sousa JB, Soares EG, Aprilli F. Effects of diclofenac sodium on intestinal anastomotic healing. Experimental study on the small intestine of rabbits. Dis Colon Rectum. 1991 Jul;34(7):613-7. PMID:2055147.

9. Rittirsch D, Huber-Lanq MS, Flierl MA, Ward PA. Immunodesign of experimental sepsis by cecal ligation and puncture. Nat Protoc. 2009;4(1):31-6. PMID: 19131954.

10. Livak KJ, Schmittgen TD. Analysis of relative gene expression data using real-time quantitative PCR and the 2(-Delta Delta $\mathrm{C}(\mathrm{T})$ ) Method. Methods. 2001 Dec;25(4):402-8. PMID: 11846609.

11. Tonini M. Recent advances in the pharmacology of gastrointestinal prokinetics. Pharmacol Res. 1996 Apr-May;33(4-5):217-26. PMID: 8938012.

12. Agren MS, Jorgensen LN, Delaisse JM. Matrix metalloproteinases and colon anastomosis repair: a new indication for pharmacological inhibition? Mini Rev Med Chem. 2004 Sep;4(7):769-78. PMID: 15379644.

13. Parks WC. Matrix metalloproteinases in repair. Wound Repair Regen. 1999 Nov-Dec;7(6):423-32. PMID: 10633001.

14. Savage FJ, Lacombe DL, Buolos PB, Hembry RM. Role of matrix metalloproteinases in healing of colonic anastomosis. Dis Colon Rectum. 1997 Aug;40(8):962-70. PMID: 9462388.

15. Pasternak B, Matthiessen P, Jansson K, Andersson M, Aspenberg P. Elevated intraperitoneal matrix metalloproteinases- 8 and -9 in patients who develop anastomotic leakage after rectal cancer surgery: a pilot study. Colorectal Dis. 2010 Jul;12(7 Online):e93-8. PMID: 19508511.

16. Kiyama T, Onda M, Tokunaga A, Efron DT, Barbul A. Effect of matrix metalloproteinase inhibition on colonic anastomotic healing in rats. J Gastrointest Surg. 2001 May-Jun;5(3):303-11. PMID: 11360054.

17. de Hingh IH, de Man BM, Lomme RM, van Goor H, Hendriks T. Colonic anastomotic strength and matrix metalloproteinase activity in an experimental model of bacterial peritonitis. Br J Surg. 2003 Aug;90(8):981-8. PMID: 12905552.

18. Marques e Silva S, Carneiro FP, Ferreira VM, Oliveira PG, Sousa JB. Effects of metoclopramide on healing of colonic anastomoses in a rat model of abdominal sepsis metoclopramide and healing of colonic anastomoses. J Invest Surg. 2013 Oct;26(5):235-41. PMID: 23514057.

19. Silva SM, Ferreira VMM, Feres O, Oliveira PG, Sousa JB. Does metoclopramide impair anastomotic healing of the left colon of rats? Acta Cir Bras. 2011 Aug;26(4):297-302. PMID: 21808843.

20. Marques e Silva S, Oliveira MVM, Brandão AM, Carneiro FP, Ferreira 
Effects of metoclopramide on the expression of metalloproteinases and interleukins in left colonic anastomoses. An experimental study

VMM, Parra RS, Feres O, Sousa JB. Study on adhesion formation and the healing of colon anastomosis in rats with induced peritoneal sepsis. Acta Cir Bras. 2011;26 Suppl 2:100-5. PMID: 22030823.

21. Silva SM, Jeronimo MS, Silva-Pereira I, Bocca AL, Sousa JB. Expression of metalloproteinases and interleukins on anastomoses in septic rats. J Surg Res. 2013 Aug;183(2):777-82. PMID: 23478082.

22. Brew K, Dinakarpandian D, Nagase H. Tissue inhibitors of metalloproteinases: evolution, structure and function. Biochim Biophys Acta. 2000 Mar 7;1477(1-2):267-83. PMID: 10708863.

23. Freedberg IM, Tomic-Canic M, Komine M, Blumenberg M. Keratins and the keratinocyte activation cycle. J Invest Dermatol. 2001 May;116(5):633-40. PMID: 11348449.

24. Ito A, Mukaiyama A, Itoh Y, Nagase H, Thogersen IB, Enghild JJ, Sasaguri Y, Mori Y. Degradation of interleukin 1beta by matrix metalloproteinases. J Biol Chem. 1996 Jun 21;271(25):14657-60. PMID: 8663297.

25. Lopes JV, Freitas LA, Marques RD, Bocca AL, Sousa JB, Oliveira PG. Analysis of the tensile strength on the healing of the abdominal wall of rats treated with infliximab. Acta Cir Bras. 2008 SepOct;23(5):441-6. PMID: 18797689.

26. DeCherney AH, diZerega GS. Clinical problem of intraperitoneal postsurgical adhesion formation following general surgery and the use of adhesion prevention barriers. Surg Clin North Am. 1997 Jun;77(3):671-88. PMID: 9194886.

27. Rongione AJ, Kusske AM, Ashley SW, Reber HA, McFadden DW. Interleukin-10 prevents early cytokine release in severe intraabdominal infection and sepsis. J Surg Res. 1997 Jul 1;70(2):107-12. PMID: 9237883.

28. Tsukada K, Katoh H, Shiojima M, Suzuki T, Takenoshita S, Nagamachi Y. Concentrations of cytokines in peritoneal fluid after abdominal surgery. Eur J Surg. 1993 Sep;159(9):475-9. PMID: 8274555.

29. Oberbeck R, Schmitz D, Wilsenack K, Schuler M, Pehle B, Schedlowski M, Exton MS. Metoclopramide and cellular immune functions during polymicrobial sepsis. Eur Surg Res. 2004 MarApr;36(2):116-22. PMID: 15007265.

30. Witte MB, Barbul A. Repair of full-thickness bowel injury. Crit Care Med. 2003 Aug;31(8 Suppl):S538-46. PMID: 12907884.

\section{Acknowledgements}

To Marcos Vinícius Melo de Oliveira, Alexandre Malta

Brandão, Pedro Henrique Alves de Morais and Naiara Galvão da Silva for their contributions to this work.

\section{Correspondence:}

Silvana Marques e Silva

SQS 405 Bloco B/205

70239-020 Brasília - DF Brasil

Tel.: (55 61)9296-1133

silvismarques@yahoo.com.br

Received: July 22, 2015

Review: Sep 19, 2015

Accepted: Oct 15, 2015

Conflict of interest: none

Financial source: none

${ }^{1}$ Research performed at Experimental Laboratory of Surgery, Faculty of Medicine, Universidade de Brasília (UnB), Brazil. 